\title{
Wetenschappelijk humanisme
}

Citation for published version (APA):

Visser, H. (1991). Wetenschappelijk humanisme. Rijksuniversiteit Limburg. https://doi.org/10.26481/spe.19911206hv

Document status and date:

Published: 06/12/1991

DOI:

10.26481/spe.19911206hv

Document Version:

Publisher's PDF, also known as Version of record

\section{Please check the document version of this publication:}

- A submitted manuscript is the version of the article upon submission and before peer-review. There can be important differences between the submitted version and the official published version of record.

People interested in the research are advised to contact the author for the final version of the publication, or visit the DOI to the publisher's website.

- The final author version and the galley proof are versions of the publication after peer review.

- The final published version features the final layout of the paper including the volume, issue and page numbers.

Link to publication

\footnotetext{
General rights rights.

- You may freely distribute the URL identifying the publication in the public portal. please follow below link for the End User Agreement:

www.umlib.nl/taverne-license

Take down policy

If you believe that this document breaches copyright please contact us at:

repository@maastrichtuniversity.nl

providing details and we will investigate your claim.
}

Copyright and moral rights for the publications made accessible in the public portal are retained by the authors and/or other copyright owners and it is a condition of accessing publications that users recognise and abide by the legal requirements associated with these

- Users may download and print one copy of any publication from the public portal for the purpose of private study or research.

- You may not further distribute the material or use it for any profit-making activity or commercial gain

If the publication is distributed under the terms of Article $25 \mathrm{fa}$ of the Dutch Copyright Act, indicated by the "Taverne" license above, 
WETENSCHAPPELIJK HUMANISME 


\title{
WETENSCHAPPELIJK HUMANISME
}

\author{
REDE
}

uitgesproken bij de aanvaarding van het ambt van bijzonder hoogleraar Humanistische Visies op Mens en Computer aan de Rijksuniversiteit Limburg op vrijdag 6 december 1991

door

Dr. H. Visser

Maastricht

Rijksuniwersiteit Limburg 

Mijnheer de Rector Magnificus.

dames en heren curatoren en bestuurders van de Stichting Socrates,

dames en heren bestuurders van de Rijksuniversiteit Limburg, dames en heren hoogleraren,

dames en heren leden van de wetenschappelijke, technische en administratieve staf,

dames cr heren studenten,

en voorts gij allen die door uw vererende aanwezigheid blijk geeft van uw belangstelling,

zeer geachte toehoorders,

\section{Inleiding}

Toen de wetenschapsfilosoof Herbert Feigl in 1949 een pleidooi hield voor wetenschappelijk humanisme ${ }^{1}$, had hij vermoedelijk niet de illusie daarmee een zoveclste stroming tot stand te brengen. Wetenschappelijk humanisten leggen de nadruk op een wetenschappelijke aanpak in de oplossing van morele problemen en daar hebben zij geen stroming voor nodig. Toch heeft het gebruik van de uitdrukking 'wetenschappelijk humanisme' voordelen: we kunnen het hebben over de geschiedenis van het wetenschappelijk humanisme in de hoop daar ons voordeel mee te doen voor de toekomst van het wetenschappelijk humanisme. 
Ook kan een wetenschappelijk-humanistisch gezichtspunt een nieuw licht werpen op ideeen en doelstellingen van schrijvers in het verleden, die anders alleen binnen de bestaande kaders worden behandeld. Het gaat hier immers om een combinatie van waarden en wetenschap, of, zo men wil, van ethiek en kennistheorie, die bi.j een gescheiden behandeling niet goed wit de verf zou komen. Het is zelfs mogelijk om denkers aan te wijzen die tegenwoordig als wetenschappelijk humanisten zouden worden beschouwd.. Speciale aandacht voor zulke denkers kan vruchtbaar zijn voor de verdere verdieping van het hedendaagse wetenschappelijk humanisme.

Voor een deel zijn de morele problemen van vandaag de dag anders dan die van wroeger. Het vraagstuk van "het mens-zijn in het computertijdperk" zoals dat in 1985 door de computerdeskundige Michael Arbib wordt geformuleerd ${ }^{2}$, is verschillend van het probleem van "het mens-zijn" dat in 1897 door de rechtsgeleerde Woodrow Wilson onder woorden werd gebracht ${ }^{3}$. Maar daarom kunnen we ook nu nog wel van Wilson leren; zoals deze zelf zei: "Gelukkig zijn we niet de eerste mensen." Dat wil zeggen, vorige generaties hebben ons een grote erfenis nagelaten, die we niet naast ons moeten laten liggen. Niet dat we daar meteen wijsheid uit kunnen putten, want "wijsheid is", om met Eduard Veterman te spreken, "geen goed dat men erven kan". "Zij moet telkens opnieuw door het individu worden verworven. Het enige wat anderen ons kunnen schenken is een wegwijzer, een gids, een methode." Deze wijze les, die indertijd een diepe indruk op mij heeft gemaakt, lijkt een waar woord voor het wetenschappelijk onderwijs in het algemeen en wellicht ook voor een inaugurele rede in het bijzonder, waarin een schets wordt gegeven van een geschiedenis van het wetenschappelijk humanisme, om daaruit lering te trekken voor "humanistische visies op mens en computer".

\section{De oudheid}

Klassiek geschoolde filosofen plegen hun betogen te beginnen met verwijzingen naar de Oudheid, daarmee te kennen gevend dat er "niets nieuws onder de zon" is." In dit geval ligt het voor 
de hand om uit te leggen dat in de Griekse Oudheid Socrates eigenlijk al een van de eerste wetenschappelijk humanisten was, niettegenstaande Aristoteles' kritiek dat deze zich alleen maar met ethiek bezighield, zonder zich af te vragen hoe de wereld in elkaar zit. ${ }^{6}$ Want wilde Socrates ethische vragen niet naar analogie van technische vraagstukken behandeld zien? Vond hij niet dat iemand die weet wat deugdzaamheid is, ook een deugdzaam leven zou kunnen leiden, zoals iemand die weet hoe een goede schoen in elkaar zit, er ook een zou moeten kunnen maken?

Afgezien van de onvolledigheid van Socrates' argument - er is tenminste ook nog oefening nodig om iets te kunnen - lijkt zijn humanisme toch wel ver af te staan van het huidige wetenschappelijk humanisme. Het is te eenvoudig om te stellen dat voor Socrates "weten" dezelfde rol speelde als "wetenschap" voor modeme wetenschappelijk humanisten.

Is Aristoteles soms een betere kandidaat om als klassiek voorbeeld van een wetenschappelijk humanist te dienen? De rol die deze geleerde aan het intellect toekent in zijn behandeling van de deugdzaamheid, wordt door commentatoren niet hoog ingeschat. ${ }^{8}$ Toch kan niet worden ontkend dat Aristoteles een goed oog had voor de problemen. Hij onderkende het bijzondere vraagstuk, hoe het mogelijk is "tegen beter weten in" te handelen, en hij zag het algemene probleem, welke invloed weten heeft op willen.'

Evenmin kan voorbij worden gegaan aan het feit dat Aristoteles het belang inzag van het overwegen en het zoeken naar de juiste middelen, toen hij goed handelen een kwestie van kiezen vond. ${ }^{10}$ Ook huldigde Aristoteles een principe waaruit volgde dat het voor mensen het beste en het aangenaamste is, als zij hun leven naar hun verstand inrichten. ${ }^{\text {" }}$ De moeilijkheid is echter dat de kloof die Aristoteles aanbrengt tussen theoretische wetenschap en het praktische leven een wetenschappelijk humanisme in de weg staat.

Dat theorie en praktijk onverbrekelijk verbonden behoren te zijn, leert de Stoïcijnse filosoof Epictetus. De Stoa wordt trouwens wel gezien als de filosofische school waarin voor het eerst humaniteit als hoogste levensdoel is ontwikkeld. ${ }^{12}$ De spreuk 'Wees mens', die eertijds de gevel van de Internationale 
School voor Wijsbegeerte sierde, is inderdaad tot colleges van Epictetus terug te voeren. ${ }^{13}$

Of met Epictetus tegelijk ook de eerste wetenschappelijk humanist is opgestaan, kan worden betwijfeld. Hoogstens had hij een wetenschappelijk-humanistisch programma toen hij zei dat een zedelijk goed mens handelt naar hetgeen hij of zij heeft leren inzien. ${ }^{14}$ Overigens moet Epictetus' invloed niet worden onderschat; zijn Enchiridion of Zedekundig handboekje is wellicht het meest uitgegeven boek op de bijbel na. ${ }^{15}$

Wie Epictetus noemt, moet ook Marcus Aurelius noemen, met zijn stelling dat alle mensen, als redelijke wezens, ook de Rede die voorschrijft wat wel en niet moet worden gedaan, gemeen hebben. ${ }^{16}$ Deze stelling werd nog in de achttiende eeuw aangehaald om aan te tonen dat de algemene principes van de ethiek streng bewezen kunnen worden. ${ }^{17}$

\section{De achtiende eeuw}

Pas in de achttiende eeuw, zo lijkt het, worden humanisme en wetenschap inderdaad expliciet met elkaar in verband gebracht. In het klassieke humanisme van Erasmus en Thomas More werd menselijke waardigheid meer in de cultuur gezien dan in natuurwetenschap en techniek. Omstreeks 1600 is Simon Stevin op dit punt de grote vemieuwer doordat hij zich de bevordering van de wetenschap als middel tot verhoging van de "ghemene welvaart" ten doel stelt. ${ }^{18}$ Vervolgens wordt Francis Bacon de filosoof van deze nieuwe ontwikkeling en naar hem wordt door de verlichte achttiende-eeuwse filosofen graag verwezen. Zij zijn het die tenslotte de grondslag leggen voor een vrij denken, waarin cultuur, wetenschap en techniek gezamenlijk ontwikkeld worden ten bate van menselijke welvaart en menselijk welzijn.

Het verschil tussen het klassieke humanisme en het wetenschappelijk humanisme van de achttiende eeuw is wel eens kort samengevat in de woorden: "Erasmus was vervangen door Voltaire". ${ }^{19}$ Toch is het de vraag of Voltaire wel zo'n "wetenschappelijk humanist" was. Hij lijkt eerder een vertegenwoordiger van een "gezond-verstandhumanisme", waar men het overigens ook al ver mee kan brengen als men 
vooroordelen en ongerechtvaardigde generalisaties aan de kaak wil stellen. In elk geval was Voltaire er mee in staat Rousseau te weerleggen toen deze door de Academie van Dijon bekroond werd voor zijn negatieve antwoord op de vraag of de kunsten en wetenschappen bijgedragen hadden aan de verbetering van de zeden; je gaat toch ook niet zeggen, zei Voltaire, dat alle Academies belachelijk zijn omdat er én gek is geworden? ${ }^{20}$

Hoewel Voltaire over de natuurkunde van Newton schrijft en daarmee een belangrijke bijdrage levert aan de verbreiding van wetenschappelijke denkbeelden, ontbreekt het hemzelf toch aan een programma van wetenschappelijk humanisme en doet hij evenmin een poging tot daadwerkelijke synthese van wetenschap en waarden. Hij neemt genoegen met de constatering dat de morele wet, "doe wat ge wilt dat men u doet", universeel is en vroeg of laat door alle mensen ter harte zal worden genomen, omdat het een consequentie is van hun gemeenschappelijke Rede. ${ }^{21}$ In het algemeen gaat Voltaire's streven naar grotere menselijke vrijheid, verdraagzaamheid en redelijkheid niet samen met een wetenschappelijke instelling.

In de gangbare benaderingen van de achttiende-eeuwse filosofie valt de nadruk op Rousseau en Kant. Uit het oogpunt van het wetenschappelijk humanisme zijn twee andere denkers sleutelfiguren: D'Alembert en Mendelssohn. Natuurlijk zijn zij nooit echt vergeten; D'Alembert, wiens naam verbonden is met een wiskundige stelling, een natuurkundig principe en met vergelijkingen, wordt voortdurend genoemd vanwege zijn veelgelezen voorrede van de Encyclopédie; Mendelssohn lijkt nog niet zo lang geleden bij de herdenking van zijn tweehonderdvijftigste geboortedag door een nieuwe generatie herontdekt. ${ }^{22}$ Maar men kan niet zeggen dat Mendelssohn en D'Alembert tot de grote filosofen worden gerekend. Toch hebben beiden, zij het ieder op een verschillende manier, een programma van wetenschappelijk humanisme en doen zij ook een poging tot synthese van wetenschap en waarden. Bovendien oefenden zij elk de nodige invloed op uit op latere generaties en tenslotte trachtte ieder van hen in zijn persoonlijke sfeer naar zijn idealen te leven.

D'Alembert's uitgangspunt komt al heel eenvoudig tot uitdrukking in zijn karakteristiek van de Rede, die aan Marcus 
Aurelius doet denken: wat wezenlijk en uniek aan de de Rede toebehoort - dus voor alle volken hetzelfde is - dat zijn de plichten waar mensen zich tegenover hun medemensen aan te houden hebben. Dat wil zeggen dat de kennis van de plichten jegens medemensen, de moraal, een van van de belangrijkste onderwerpen is waar de Rede kan worden uitgeoefend. ${ }^{23}$ Bij D'Alembert vinden we dan ook een exact-wetenschappelijke behandeling van deze moraal, die gebaseerd is op zgn. gevoelswaarheden zoals het bestaan van een vrije wil. Kennelijk gaat D'Alembert hier te werk naar analogie van zijn behandeling van de theoretische mechanica, waarin hij met behulp van het axioma van het bestaan van beweging speciale principes afleidt.

Dit lijkt ongelooflijk en D'Alembert zou zelfs van naïviteit kunnen worden beschuldigd als hij niet tevens een schets had gegeven van het specifieke vraagstuk van een rechtvaardige inkomensverdeling. Hiervoor zijn volgens hem drie dingen nodig: ten eerste, een algemene theorie, gebaseerd op hypothesen en definities, warin stellingen kunnen worden afgeleid; ten tweede, meetprocedures, waarmee bijvoorbeeld kan worden vastgesteld hoeveel geld individuele mensen, met hun verschillende constituties, op een bepaald moment hebben, respectievelijk nodig hebben om in hun absoluut noodzakelijke levensbehoeften te kunnen voorzien; en ten derde, berekeningen op grond van theorie en meetprocedures, waaruit consequenties worden getrokken voor een betere inkomensverdeling. ${ }^{24}$ Hier lijkt D'Alembert's voorbeeld de technische mechanica, waarin sinds Stevin conclusies worden getrokken voor het vervaardigen van openbare werken.

Het is gemakkelijk om schamper te doen over deze "ingenieursfilosofie", maar er kan ook worden vastgesteld dat D'Alembert er toch maar in slaagde, Socrates' analogieredenering met technische produkten de wetenschappelijke vorm te geven, die tegenwoordig in de welvaartseconomie niet ongewoon is, al wordt het normatieve karakter van metingen van ongelijkheid daar niet overal even sterk beklemtoond. ${ }^{25}$ Voor D'Alembert was het een kwestie van humaniteit die hemzelf ook aanging; toen hij in zijn latere leven door verschillende jaargelden ver boven het bestaansminimum zat, gaf hij een deel van zijn overschot aan mensen uit zijn omgeving die daar anders 
onder zouden zitten. Geen wonder dat D'Alembert door de Schotse filosoof en historicus Hume als toonbeeld van een deugdzaam en filosofisch figur werd beschouwd. ${ }^{26}$

De Duitse Socrates werd hij genoemd, zelfs de derde Moses, Moses Dessau, die zijn Duitstalige geschriften ondertekende met Moses Mendelssohn. In tegenstelling tot $D^{\prime}$ Alembert is Mendelssohn nooit lid van de Berlijnse Academie van Wetenschappen geworden, maar dat lag njet aan een gebrek aan wetenschappelijk aanzien; zijn benoeming werd alleen niet bekrachtigd door de koning van Pruisen. Zo bleef hij alleen zijn vrije tijd aan de studie van kunsten en wetenschappen besteden, wat niet wil zeggen dat dit voor hem zomaar een vrijetijdsbesteding was; deze studie was nodig, zo zei hij, om al zijn meningen en handelingen te kunnen toetsen. ${ }^{27}$

De Rede ("die Vernunft") speelt bij Mendelssohn een beslissende rol bij zijn morele handelen. Een van zijn scherpste uitspraken kan zelfs als een negatieve uitdrukking van wetenschappelijk humanisme worden gezien: "Indessen entstehet der Vernunfthass und der Menschenhass auf eine ăhnliche Weise". ${ }^{28}$ (Haat tegen de Rede en haat jegens mensen ontstaan op analoge wijze.)

Mendelssohn's wetenschappelijke benadering van het humanisme ligt vooral op het gebied van de begripsprecisie. Zijn taalkritische instelling past overigens wonderwel bij zijn respect voor het individu. Hiermee heeft hij de grondslag gelegd voor het moderne wetenschappelijk humanisme, waarin morele principes zo geformuleerd worden dat zij betrekking hebben op individuele mensen van vlees en bloed, en niet op "gemiddelden", laat staan op algemene abstracties. ${ }^{29}$ Een van de beste bewijzen voor deze wetenschappelijke instelling treffen we aan in een brief van Mendelssohn aan ene August von Hennings. Deze had zich erover beklaagd dat de menselijke soort zo weinig vooruitging. Mendelssohn antwoordde dat de bedoeling van de natuur niet de vervolmaking van de menselijke soort is, maar de vervolmaking van de mens, het individu, in die zin dat ieder individueel mens zijn aanleg en vaardigheden moet ontwikkelen. Scherp wijst hij Hennings terug als hij schrijft: "De menselijke soort als zodanig is geen op zichzelf bestaand wezen; zij bestaat veeleer uit individuele mensen". 
Ook in Mendelssohn's "humanistisch manifest", zijn verhandeling over de vraag "wat houdt verlichten in" ("Was heisst Aufklären?"), ${ }^{31}$ komt zijn behoefte aan betere begripsbepalingen naar voren. Mendelssohn brengt hier een tweedeling aan tussen "cultuur" en "verlichting"; bij cultuur gaat het meer om praktische, ambachtelijke, artistieke en sociale vaardigheden en de produkten daarvan; bij verlichting gaat het meer on verstandelijk nadenken over de dingen van het menselijk leven en de daaruit voortvloeiende kennis. Maar dat betekent niet dat er bij hem van twee gescheiden culturen sprake is, om met Charles Snow te spreken. Alleen waar cultuur en verlichting gelijk opgaan, zijn zij voor elkaar de beste voorzorgsmiddelen tegen bederf of corruptie. De combinatie van cultuur en verlichting heet pas "beschaving", "Bildung" in het Duits.

Het is eigenaardig dat in de literatuur bijna steeds alleen naar Kant's beantwoording van de vraag "wat is verlichting" ("Was ist Aufklärung?") wordt verwezen, terwijl Mendelssohn's opstel uit begripskritisch oogpunt al zoveel meer terzake is. Wellicht was veel verwarring voorkomen als Mendelssohn's voorstellen voor het gebruik van de woorden "Aufklärung", "Cultur" en "Bildung" algemeen waren overgenomen. Bovendien was dan wellicht het normatieve karakter van die woorden meer tot de gebruikers ervan doorgedrongen. Over het laatste bestaat bij Mendelssohn geen enkel misverstand als hij beklemtoont dat de bestemming van de mens altijd zijn richtsnoer is geweest. "Bildung", cultuur en verlichting zijn het resultaat van menselijke inspanningen om hun sociale toestand te verbeteren.

Mendelssohn's nadruk op taal is een opvallend verschil met Kant; een taal verkrijgt verlichting door de wetenschappen, en cultuur door sociale omgang, poëzie en welsprekendheid. Door de eerste wordt een taal geschikter voor theoretisch, door het tweede voor praktisch gebruik. Volgens Mendelssohn is trouwens de taal van een volk de beste aanwijzing voor zijn beschaving. Hoezeer Mendelssohn over taalgebruik nadacht, blijkt uit zijn onverhulde kritiek op de filosofie van zijn tijd, als hij de beruchte controversen tussen filosofische scholen terugvoert op louter woordenstrijd $\mathrm{d}^{32}$ - een conclusie die Kant's geïrriteerdheid opwekte, maar daarom nog niet onjuist hoeft to zijn. Niet geheel 
los van deze opvatting staat zijn humanistische beginselverklaring dat de werkelijkheid alleen te begrijpen is met een beroep op menselijke vermogens: "ik erken geen andere eeuwige waarheden dan die welke niet alleen begrijpelijk zijn voor de menselijke Rede, maar ook door menselijke krachten kunnen worden aangetoond en bevestigd". ${ }^{33}$

Tenslotte lijkt het niet overbodig om te vermelden dat deze Duitse Socrates wel gewicht toekende aan oefening; het samengaan van humanisme met wetenschap moet geleerd worden. Het geweten is het resultaat van permanente oefening van onze intellectuele krachten. ${ }^{34}$ Wat dit betreft kan de derde Moses zeker worden opgenomen in de rij van grote figuren die zijn aan te merken als voorlopers van de "éducation permanente" ${ }^{\text {35 }}$

\section{De negentiende eeuw}

Naast wetenschappelijk-humanistische ideeën hielden D'Alembert en Mendelssohn er ook opvattingen op na die moderne wetenschappelijk humanisten niet meer zouden onderschrijven; zo erkennen bijvoorbeeld beiden op intellectuele gronden het bestaan van een opperwezen. Het zijn echter de genoemde vernieuwingen van $D^{\prime}$ Alembert en Mendelssohn die indruk maakten op jongere tijdgenoten en hun volgelingen. D'Alembert's programma voor de toepassing van exacte methoden in de moraal werd al door Condorcet uitgebouwd tot een nieuwe wetenschap, sociale wiskunde genoemd; ${ }^{36}$ aan Mendelssohn's programma voor grotere individuele wetenschappelijke en culturele ontwikkeling werd door Wilhelm van Humboldt gestalte gegeven in zijn voorstellen voor de organisatie van de hogere wetenschappelijke instellingen in Berlijn. ${ }^{37}$ Uit zijn nagelaten handschriften blijkt hoe nauw Humboldt bij Mendelssohn aansloot. Diens doel van "de bestemming van de mens" wordt letterlijk door hem overgenomen. Hij geeft aanzetten tot een "Theorie der Bildung" en hij formuleert een individualiteitsleer ${ }^{38}$ Samen gaan deze theorieẻn uit van het principe dat elk individueel mens uniek en gedurende zijn of haar hele leven onaf is. 
Mendelssohn's terminologie van verlichting en cultuur keert letterlijk terug in Humboldt's "Ideeën voor een poging om de grenzen wan de werkzaamheid van de Staat te bepalen" uit 1792. Weliswaar werd dit werk pas in 1851 volledig uitgegeven, maar toen miste het zijn uitwerking niet; John Stuart Mill's boek "Over vrijheid" is er de directe opvolger van. ${ }^{39}$ Ook is de invloed nog merkbaar in "The subjection of women" (De onderdrukking van vrouwen). ${ }^{40}$ Zo is Mendelssohn's gedachtengoed indirect tot Groot-Brittannie doorgedrongen.

Op de negentiende-eeuwse continentale filosofen hadden D'Alembert en Mendelssohn weinig invloed; maar deze hadden op hun beurt nauwelijks iets te zeggen aan de negentiendeeeuwse beoefenaren van de exacte wetenschappen die zelf de grondslagen van hun theorieën gingen onderzoeken, een verschijnsel dat "de wetenschappelijke wending" kan worden genoemd. ${ }^{41}$

Toen Condorcet"s "Schets van een historisch overzicht van de vorderingen van de menselijke geest" in 1847 voor het eerst in druk verscheen, was zijn "tiende tijdperk van de toekomst" nog niet aangebroken; nog steeds waren de ongelijkheden tussen staten niet opgeheven, er waren geen gelijke rechten voor mannen en vrouwen, niet alle mensen waren vrije burgers en er was nog geen sprake van een continue verbetering van ieders levensomstandigheden. Maar dat de kennis van de natuur al een aanzienlijke positieve bijdrage had geleverd aan de materiële welstand en het geestelijk welzijn van de vollkeren van Europa, kon volgens een andere leerling uit de kring van Mendelssohn, Alexander von Humboldt, zelfs door de grootste reactionair niet meer worden ontkend. ${ }^{42}$ En de Duitse econoom Gossen schrijft geheel in de geest van D'Alembert het eerste wiskundigeconomisch werk, waarin wetenschappelijk wordt aangetoond dat niets een paradijs op aarde in de weg hoeft te staan....43

Het is duidelijk dat de geestelijke nazaten van de gebroeders Humboldt nogal optimistisch waren over de vooruitgang in het wetenschappelijke tijdperk, zoals zij hun tijd zagen. Hierin lijken zij van D'Alembert en Mendelssohn te verschillen. Dezen hadden met zoveel woorden een terugval in de barbarij zeker voor mogelijk gehouden. Toch was ook de meest consequente wetenschappelijk humanist van de negentiende-ceuw, de Engelse 
wiskundige en wetenschappelijke filosoof William Kingdon Clifford niet onverdeeld optimistisch. Het is waar dat volgens hem wetenschappelijk denken "de vooruitgang zelve" is, maar daarmee is niet gezegd dat wetenschappelijk denken altijd in ere zal worden gehouden; "het is heel goed mogelijk dat de morele en intellectuele cultuur van Europa wordt weggevaagd door een herleving van bijgeloof". ${ }^{44}$

Clifford deed in 1875, in zijn verhandeling "Goed en slecht; de wetenschappelijke basis voor hun onderscheid" een poging om morele gevoelens en wetenschappelijke methoden samen te brengen. ${ }^{45}$ Hij betoogde, in de geest van D'Alembert, dat een wetenschappelijke behandeling van ethiek mogelijk is; hij stelde, in de geest van Mendelssohn, dat morele noties, inclusief menselijke waarden, zo moeten worden opgevat dat zij vrij zijn van onwetenschappelijke opvattingen. Dat wil zeggen, Clifford zag ten eerste in dat wetenschappelijke methoden zo moeten worden opgevat dat traditionele opvattingen over ondeugdelijkheid van wetenschappelijk onderzoek en wetenschappelijke resultaten voor de realisering van menselijke waarden er geen vat op hebben, en ten tweede dat menselijke waarden zo moeten worden opgevat dat zij bevrijd worden van onwetenschappelijke, zoals metafysische ideologieën.

Wetenschappelijke methoden worden door Clifford niet beperkt tot natuurwetenschappelijke behandelingen; hij erkent die ook in de psychologie en de sociologie, waarin opvattingen, gevoelens, bedoelingen, wensen e.d. aan mensen worden toegeschreven; daar wordt, met andere woorden, menselijk gedrag in $\mathrm{zgn}$. intentionele taal verklaard. Wat dat betreft nam Clifford alvast een voorschot op de ontwikkeling van deze laatste wetenschappen. En alsof hij Gossen gelezen had, schreef hij dat de wetten van de politieke economie net zo hard zijn als de wet van de zwaartekracht. De kwestie is alleen dat men er gebruik van moet maken, net zoals dat in de weg-en waterbouw gebeurt met de wet van de zwaartekracht. "Zij die de tekenen des tijds verstaan lezen erin, dat het koninkrijk des mensen ophanden is". ${ }^{46}$ 


\section{De twintigste eeuw}

Hoe goed doordacht Clifford's wetenschappelijk humanisme ook was, zijn directe invloed lijkt gering. Hiervoor zijn verschillende verklaringen te geven; hij stierf jong, op 33-jarige leeftijd, nog voordat hij in de gelegenheid was geweest zijn denkbeelden toe te passen op de problemen van zijn tijd. Ook is opgemerkt dat Clifford leefde in de hoogtijdagen van het negentiende-eeuwse liberalisme en niet kon voorzien in welke mate klasseconflicten en nationale botsingen de situatie zouden compliceren. ${ }^{47}$

Daamaast veranderde het intellectuele klimaat in Europa sinds het laatste kwart van de negentiende eeuw. Samenbrengen van wetenschappelijke methoden en morele gevoelens bleek niet haalbaar. Wetenschappelijke onderzoekers hadden al genoeg aan zuiver wetenschappelijke problemen; ethiek lieten zij, uitzonderingen zoals Mach en Poincaré daargelaten, graag over aan politieke leiders, pedagogen, schrijvers en dichters. Filosofen, en zij niet alleen, voelden zich geroepen om tegenstellingen te benadrukken; wetenschap tegenover waarden, natuurwetenschappen tegenover geesteswetenschappen, reflectie tegenover intuitie, verstand tegenover gevoel en zelfs wetenschap tegenover mystiek. Daarbij kozen velen dan ook nog eens voor de geesteswetenschappen of, in het algemeen, voor een geildealiseerde gevoelskant. Men moet niet vergeten dat de wetenschappelijke wending zich aan het eind van de vorige eeuw al grotendeels heeft voltrokken; algemene filosofische vragen worden beperkt tot grondslagenproblemen van de wetenschappen. Wetenschappelijke filosofen vragen zich bijvoorbeeld niet meer af wat "ruimte" en "tijd" zijn, maar onderzoeken de structuur van de ruimte- en tijdstheorieěn die deel uitmaken van natuurkundige theorieèn. ${ }^{48}$

Voor filosofen die de wetenschappelijke ontwikkingen niet meer konden volgen, zat er niet veel anders op dan filosofische theorieen te bedenken die weinig of niets met wetenschap te maken hadden. Dit bracht met zich mee dat zij geen effectief antwoord konden geven op de problemen van hun tijd die het gevolg waren van ontwikkelingen in wetenschap en techniek.

Natuurlijk waren er ook reacties: in Engeland verdedigde Russell vlak voor de eerste wereldoorlog "de wetenschappelijke 
methode in de filosofie" maar deze was uitdrukkelyk alleen gericht op het begrijpen van de wereld en niet op het verbeteren van het leven. ${ }^{49}$ Bij wetenschap ging het immers om feiten en niet over ethische noties... Russell's leerling Wittgenstein gaf zelfs een logisch-filosofische draai aan dit dualisme door het onderscheid tussen "hoe iets is" en "hoe het zou moeten zijn" te laten corresponderen met "wat gezegd kan worden" en "wat alleen mar getoond kan worden". Morele dilemma's zouden alleen kunnen worden duidelijk gemaakt aan de hand van gelijkenissen, fabels, mythen, e.d., d.w.z. door middel van analogieën. ${ }^{51}$

In de Verenigde Staten, het land van Woodrow Wilson, is het echter John Dewey die in zijn "Reconstruction in philosophy" van 1920 het dualisme wil opheffen. ${ }^{52}$ De indruk die de eerste wereldoorlog op hem had gemaakt was hier niet helemaal vreemd aan; Dewey stelde vast dat natuurwetenschappelijke disciplines ethisch worden zodra zij bijdragen leveren aan de ontdekking van concrete menselijke ellende en aan de ontwikkeling van plannen om die te verhelpen of te verlichten. Maar dit houdt tegelijkertijd in dat de ethiek zelf niet alleen haar extreem moralistische karakter, maar ook haar vaagheid verliest; die wetenschappelijke bijdragen gaan een integrerend bestanddeel van de ethiek wormen.

Dewey heeft in die tijd de droom van een wereld waarin de kloof tussen het materièle, het mechanische, het wetenschappelijke, en het morele, het ideale is geslecht. Wetenschap en humanisme zijn daar ến geworden. Weliswaar spreekt hij niet van een paradijs op aarde, of van het koninkrijk des mensen, maar wel voorziet hij, net zoals Alexander von Humboldt, een continu proces van verbetering van welvaart en welzijn.

Een kleine dertig jaar later, na de tweede wereldoorlog, moet Dewey, in een nieuwe inleiding bij de heruitgave van het genoemde boek, vaststellen dat de resultaten van wetenschappelijk onderzoek hoe langer hoe meer het leven van iedereen doordrenken, zonder dat binnen de wetenschap zelf of in een bestaande ethische theorie de middelen aanwezig zijn om de consequenties voor menselijke waarden te analyseren en te evalueren. ${ }^{53} \mathrm{Nu}$ zouden er wetenschapsbeofenaren kunnen zijn, 
die beweren dat de morele problemen die verbonden zijn met de effecten van wetenschap en techniek, door die wetenschap en techniek zelf ook zullen worden opgelost; maar er zouden ook critici kunnen zijn, die beweren dat wetenschap en techniek alleen maar mér morele problemen zullen opleveren. Vrij vertaald komt Dewey's diagnose er op neer dat geen van beide groepen hun beweringen kunnen waarmaken; daarvoor ontbreekt het hun aan de geschikte instrumenten om die problemen te bepalen of aan te pakken. Vandaat dat Dewey in 1948 pleit voor een morele menselijke wetenschap waarin deze instrumenten wel worden ontwikkeld.

Nog geen jaar later schrijft Feigl zijn manifest waarin hij een wetenschappelijk humanisme voor mogelijk houdt. Er is weinig fantasie voor nodig om te veronderstellen dat Feigl geïnspireerd werd tot zijn wetenschappelijk-humanistisch manifest door lezing van de indrukwekkende poging tot synthese van de hoogbejaarde Dewey. Maar men hoeft ook niet over veel inzicht te beschikken om te vermoeden dat de mogelijkheid van zo"n synthese theoretisch of theologisch zou worden aangevochten. In 1966 voelde Feigl zich dan ook nogmaals genoodzaakt tot wetenschappelijk humanisme op te roepen, maar ditmaal was zijn appdl dwingender: "als wij onszelf op deze planeet niet willen vernietigen door het immorele en stupide gebruik van onze wetenschappen en onze technologische macht, als we onze macht willen gebruiken voor de verbetering van het menselijk bestaan, dan is datgene waar we het meest dringend behoefte aan hebben, een nieuw tijdperk van verlichting, zowel in wetenschappelijk als in ethisch opzicht". ${ }^{44}$

\section{Mens en computer}

Vijfentwintig jaar later kunnen we vaststellen dat er nog steeds geen sterk wetenschappelijk-humanistische stroming is, terwijl toch de doordrenking van wetenschap en techniek van het dagelijkse leven alleen maar sterker is geworden. Wel begint het besef door te dringen dat de zgn. milieuproblematiek alleen kan worden opgelost door een synthese van wetenschappelijk onderzoek en de effectieve erkenning van de noodzaak van een 
leefbare wereld voor toekomstige generaties. De negatieve effecten van technische produktie en produkten op de levensvoorwaarden op "onze planeet" zijn meetbaar geworden. Als het gaat om "natuurlijke" menselijke waarden zoals gezondheid, hoeft men geen wetenschappelijk humanist te zijn om te erkennen dat een wetenschappelijke aanpak vereist is om zulke waarden te realiseren.

Wat met name de effecten van de invoering van computers betreft, is de situatie niet zo duidelijk. Hier gat het om morele waarden zoals vrijheid, maar ook privacy en individualiteit en aantastingen daarvan laten zich moeilijker vaststellen dan aantasting van de gezondheid, laat staan van een ozonlaag. Hoewel de analytische verheldering van morele noties sinds 1960 een grote vlucht heeft genomen, is het niet evident dat het vraagstuk van de morele consequenties van computertechnologie wetenschappelijk kan worden aangepakt.

Dit laat niet weg dat geinteresseerde humanisten hun standpunten ten aanzien van de zgn. computerrevolutie al bepaald hebben. Er kunnen twee uitersten worden onderscheiden, die hier gemakshalve de neo-mechanistische en de neo-mysticistische worden genoemd. Beide hebben namelijk een zekere verwantschap met posities die ten tijde van de $z \mathrm{gn}$. machinerevolutie werden ingenomen, ofschoon neomechanistische humanisten verschillen tussen computers en traditionele machines beklemtonen, en neo-mysticistische humanisten overeenkomsten.

Neo-mechanistische humanisten zien met stijgende bewondering naar de mogelijkheden die computers bieden, zoals het uit handen nemen van geestdodend, slopend of gevaarlijk werk, het helpen bij of zelfs ovememen van intellectuele activiteiten en het vergroten van de communicatiemogelijkheden. Als het gaat om de vergelijking tussen mensen en machines, dan wordt door hen vastgesteld dat de stelling van de discontinulteit tussen mensen en machines niet langer houdbaar is, omdat computergestuurde machines in intellectueel opzicht hoe langer hoe meer op mensen gaan lijken. ${ }^{5 s}$ Het gedrag van deze machines kan alleen nog maar verklaard en begrepen worden in de intentionele taal waar Clifford al op gewezen had. En als Wittgenstein gelijk heeft dat morele keuzen voornamelijk 
worden gedaan op grond van analogieën, dan kan worden opgemerki dat er nu al machines zijn die analogieën kunnen zien. De weg is open voor een moreel expertsysteem ("morality machine"), dat begrippen als "verraad" en "samenwerking" niet alleen kan representeren, maar ze ook op verschillende situaties kan toepassen. ${ }^{56}$

Volgens Margaret Boden, aan wie deze gedachtengang is ontleend, hangen veel potentielle negatieve effecten van de invoering van hoe langer hoe intelligenter machines af van de onjuiste opvatting dat "mechanisme" en "menselijke kwaliteiten" onverenigbaar zijn. Zij gaf zelfs een wetenschappelijk-humanistisch tintje aan deze krasse stelling, door er, in de geest van Mendelssohn, een nog algemenere stelling mee te verbinden; "als mensen denken dat wetenschap een mensbeeld biedt dat onverzoenlijk is met humanisme, dan moeten zij of hun menselijkheid ontkennen - met sociaal verwoestende resultaten - of anders wetenschappelijk inzicht in de mensheid prijsgeven". ${ }^{57}$

Voor neo-mysticistische humanisten is de uitvinding en ontwikkeling van computers daartegen aanleiding om met stijgende bewondering te kijken naar de exclusieve mogelijkheden die mensen alleen al in intellectueel opzicht hebben, zoals creativiteit, flexibiliteit en openheid. Zelfs zogenaamde expertsystemen zouden niet aan deze mogelijkheden toekomen omdat de programma"s ervan gebonden zijn aan bepaalde gesloten structuren, terwijl de genoemde eigenschappen juist het doorbréken van bestaande structuren inhouden. Degenen die suggereren dat bijvoorbeeld medische expertsystemen een diagnose zouden kunnen stellen, bezondigen zich aan een gevaarlijke misleiding van potentiële gebruikers; voor het stellen van een echte medische diagnose zijn namelijk die exclusief menselijke eigenschappen onontbeerlijk. ${ }^{58}$

Volgens Terry Winograd, aan wie deze gedachtengang is ontleend, houdt dit in dat expertsystemen alleen nuttig kunnen zijn als de gebruikers ervan werkelijk begrijpen wat deze doen, doordat zij de beperkingen van zulke systemen door en door kennen. Deze eis komt er in feite op neer dat alleen de experts zelf van expertsystemen gebruik mogen maken.

Hoezeer de neo-mechanistische en de neo-mysticistische humanisten ook van mening verschillen, beide partijen blijven 
humanisten die de algemene stelling onderschrijven die ooit eens fraai verwoord werd door de Nederlandse minister van wetenschapsbeleid Van Trier. In zijn rede "Micro-electronica en de kwaliteit van de mens" zei deze:" "Het moet ons erom te doen zijn ook deze technologie in dienst te stellen van de bevrijding en verrijking van de mensen en niet voor de vergroting van de serviliteit en de geestelijke verarming". ${ }^{59}$

Wel worden door neo-mechanistische en neo-mysticistische humanisten verschillende zogenaamde scenario's voor de toekomst geschetst. Dit kan wellicht ook het beste worden duidelijk gemaakt aan het voorbeeld van expertsystemen. Terwijl neo-mysticistische humanisten de rol van de experts bij expertsystemen alleen maar willen vergroten, vinden neomechanistische humanisten het juist gewenst dat de mystiek die er om menselijke experts hangt door de invoering van expertsystemen wordt teruggedrongen en de macht van de experts wordt verminderd. ${ }^{60}$

Toch is het niet zo dat deze twee visies ons voor een dilemma plaatsen en we voor of tegen én ervan moeten zijn. Op de keper beschouwd zijn geen van beide opvattingen op een solide basis gefundeerd. De neo-mysticistische humanisten, die zich verzetten tegen een zogenaamde "rationalistische traditie", ontlenen hun noties en argumentaties voornamelijk aan antiwetenschappelijke fillosofische theorieën. Voor zover de neomechanistische humanisten zich rekenschap geven van de grondslagen van hun conclusies, lijkt het alsof zij zich wel op wetenschappelijke resultaten beroepen. Toch baseren ook zij zich op een filosofische theorie, computationalisme genaamd, die op zijn gunstigst verbonden is met een zeer heterogeen wetenschappelijk onderzoeksprogramma, de zgn. cognitiewetenschap. ${ }^{6}$

Het is nu niet moeilijk meer om een alternatief aan te geven in de vorm van een wetenschappelijk-humanistische benadering van mogelijke morele consequenties van computertechnologische beslissingen, of die nu betrekking hebben op expertsystemen, geautomatiseerde betaalsystemen, gecomputeriseerde strafzaakbehandelingen, databanken of opererende robots. Zonder in details te vervallen kan in een vijftal punten opgesomd worden, waar zo'n benadering tenminste aan zou moeten voldoen.

Ten eerste dient een zo volledig mogelijk overzicht te 
worden gemaakt van de menselijke morele waarden die in het geding kunnen zijn. Al genoemd werden vrijheid, privacy en individualiteil. Bekend zijn ook verdraagzaamheid, verantwoordelijkheden en verschillende vormen van verbondenheid; "humaniteit" is een meer algemene waarde, die o.a. menselijke waardigheid, medemenselijkheid en integriteit omvat.

Ten tweede dient een zo nauwkeurig mogelijke interpretatie aan elk van deze noties te worden gegeven, waardoor het mogelijk wordt in voorkomende gevallen vast te stellen in hoeverre de betreffende waarde in acht wordt genomen. Deze heet dan "voorlopig geoperationaliseerd".

Ten derde wordt een overzicht gemaakt van technologische vemieuwingen waarvan kan worden aangenomen dat deze invloed kunnen uitoefenen op bestaande waarden.

Ten vierde worden op grond van wetenschappelijk vastgelegde ervaringen scenario"s ontworpen waarin de gesignaleerde technologische vernieuwingen in bepaalde mate zijn doorgevoerd.

Ten vijfde wordt voor elk van die scenario's en elk van de zonodig nader geoperationaliseerde waarden de vraag beantwoord of deze waarde binnen dat scenario tenminste intact blijft. Hierbij hoort ook de vraag naar mogelijk misbruik van computervoorzieningen.

Het doel is duidelijk: de verkregen antwoorden dienen te worden aangegrepen om zonodig ingezette ontwikkelingen bij te sturen. Eenvoudig gezegd komt de hele procedure, of het hele programma, er op neer dat beweringen over mogelijke versterking dan wel aantasting van bepaalde fundamentele morele menselijke waarden door technologische ontwikkelingen zo goed mogelijk onderbouwd worden. Dit is op zichzelf natuurlijk geen schokkende conclusie, maar tot nu toe ontbreekt het veelal aan zo'n onderbouwing. Als dit komt doordat de analytische, wetenschappelijke èn computertechnische instrumenten daartoe nog steeds te weinig ontwikkeld zijn, dan is de verdere ontwikkeling van deze instrumenten een eerste taak voor het moderne wetenschappelijk humanisme. 
Dames en heren curatoren en bestuurders van de Stichting Socrates,

Graag spreek ik mijn erkentelijkheid uit voor het door u aan mij geschonken vertrouwen om mij te benoemen op een leerstoel die uniek is in het Nederlandse universitaire bestel. $U$ kunt ervan vezekerd zijn, dat ik mijn uiterste best zall doen mijn taak goed te vervullen.

Dames en heren bestuurders van de Rijksuniversiteit Limburg.

De methode van probleemgestuurd onderwijs is direct gebaseerd op de opvatting dat wijsheid telkens opnieuw door elke individuele student zelf moet worden werworven. Dat ik door uw instemming met mijn benoeming deze methode in de praktijk kan brengen, stemt mij met dankbaarheid.

Een woord van dank geldt ook de bestuurders van de Katholieke Universiteit Brabant, die het mij mogelijk maakten deze taak naast mijn bestaande werkzaamheden op mij te nemen.

Dames en heren leden van de Faculteit der Algemene Wetenschappen,

Uw faculteit is in korte tijd van een dienstverlenings- en onderzoeksinstituut veranderd in een faculteit met twee eigen studierichtingen, Cultuur- en Wetenschapsstudies en Kennistechnologie. Ik hoop dat deze twee studierichtingen zich. in harmonie met elkaar zullen ontwikkelen. Op mijn steun kunt u daarbij rekenen.

Hooggeleerde Van den Herik,

Onder uw bezielende leiding is de vakgroep Informatica al een begrip geworden. Het lidmaatschap van deze vakgroep beschouw ik als een groot voorrecht. 
Hooggeleerde Doorman,

U hebt gedurende acht jaren op zo"n voorbeeldige wijze aan mijn "Bildung" bijgedragen, dat ik graag van de gelegenheid gebruik maak in het openbaar van mijn dankbaarheid blijk te geven.

\section{Zeergeleerde Birner,}

Zeven jaar geleden verzorgden wij een boeiend doctoraalcollege voor studenten van de Economische Faculteit aan de Erasmus Universiteit Rotterdam. Het verheugt mij dat wij onze samenwerking in Maastricht kunnen voortzetten.

Dames en heren studenten,

De Universiteit is nog steeds een instelling waar studenten in belangrijke mate voor hun verdere leven gevormd worden. Ik hoop aan deze vorming bij te dragen door u wegwijs te maken in de humanistische visies op mens en computer. 


\section{Noten}

1. Herbert Feigl, "Naturalism and humanism", American Quarterly 1 (1949), pp. 135-148, o.a. herdrukt in: Herbert Feigl, Inquiries and provocations. Selected writings 1929-1974, edited by Robert S. Cohen, Dordrecht: D. Reildel, 1981, pp. 366-377.

2. Michael A. Arbib, "On being human in the computer age", in: Impacts of artificial intelligence, edited by R. Trappl. Amsterdam [etc]: North-Holland, 1986, pp. 52-63.

3. Woodrow Wilson, On being human, New York and London: Harper and Brothers, 1916, oorspronkelijk verschenen in Atlantic Monthly (1897).

4. Eduard Veterman, Essais, 1941 (niet in de handel) p. 15.

5. Prediker $I, 9$.

6. Aristoteles, Metaphysica $\mathbb{I}$, vi, 987.

7. Vergelijk: Heinrich Gomperz, Die Lebensauffassung der Griechischen Philosophen und das Ideal der inneren Freiheit, Zweite Auflage, Jena: Eugen Diederichs, 1915, p. 96.

8. Vergelijk: Richard Sorabji, "Aristotle on the role of intellect in virtue", in. Essays on Aristotte's ethics, edited by Amélie Oksenberg Rorty, Berkeley [etc.]: University of California Press, 1980, pp. 201219, oorspronkelijk verschenen in Proceedings of the Aristotelian Society, n.s. 74 (1973-1974), pp. 107-129.

9. Vergelijk: Theodor Gomperz, Griechische Denker, Dritter Band, Leipzig: Veit \& Comp.. 1909, p. 219.

10. Vergelijk: Richard Sorabji, o.c.n p. 208.

11. Naar een bekende passage wit Aristoteles' Nikomachische Ethiek ( $X$, 7,1178 ), ook geciteerd door Wilhelm von Humboldt in diens Ideen zu einem Versuch die Grenzen der Wirksamkeit des Staats zu bestimmen. 
12. Vergelijk" Ph. Kohnstamm, "Humanisme", in: Winkler Prins Algemeene Encyclopaedie, Vijfde druk, Negende deel, Amsterdam: Elsevier, 1935, pp. 512-513.

13. Naar: Adolf Bonhöfer, Eplctet und die Stoa, Stuttgart: Ferdinand Enke, 1890 , p. 13, n.a.v.: Epictetus, Diatriben II, $15,13$.

14. Epictetus, Diatriben II, 11, 24, naar de vertaling van: D.C. Hesseling, De kolleges van Epictetus, Haarlem: H.D.Tjeenk Willink \& Zoon, 1931, p. 147.

15. Zie: D.F. Scheurleer, "Inleiding" in: Epictetus, Enchiridion, Zedekundig handboekje, "s-Gravenhage: Martinus Nijhoff, Zesde druk, 1951 en de daarin opgenomen "Bibliographie". Vergelijk ook: F. Vleeskens, "Epictetus over vrijheid - een uitgangspunt voor onderzoek naar zijn invloed", in: Filosofische Reeks 6 (1980), pp. 21-26 (uitgave van Centrale Interfaculteit, Universiteit van Amsterdam).

16. Marcus Aurelius, Gesprekken met zichzelf, $\mathbb{I V}, 4$.

17. Moses Mendelssohn, Abhandlung über die Evidenz in metaphysischen Wissenschaften, Vierter Abschnitl, in: Moses Mendelssohn, Gesammelte Schriften, in: Jubiläumsausgabe (JubA), Stuttgart - Bad Canstatt: Friedrich Frommann, 1971-1974; 1974 ff, $J u b A, 1.2$, pp. 315-316.

18. Vergelijk: EJ. Dijksterhuis, Simon Stevin, "s-Gravenhage: Martinus Nijhoff, 1943, p. 339.

19. Charles Frankel, "The philosophy of the enlightenment", in: $A$ history of philosophical systems, edited by Vergilius Ferm, New York: The Philosophical Library, 1950, p. 267.

20. Vergelijk: Henri Gouhier, Rousseau et Voltaire, Paris: J. Vrin, 1983, p. 49.

21. Voltaire, Elémens de philosophie de Newton, Première Partie, Chapitre VI.

22. Zie: Ich handle mil Vermunft... Moses Mendelssohn und die europaische Aufklärung, herausgegeben von Norbert Hinske, Hamburg: Felix Meiner, 1981. 
23. D'Alembert, Essais sur les elemens de philosophie, VII, in: D'Alembert, Oeuvres completes, $I_{\text {, pp. } 207-208 .}$

24. D'Alembert, Essais sur les elemens de philosophie, VIII. in: D'Alembert, Oeuvres completes I, pp. 214-215.

25. Vergelijk; Amartya Sen, On economic equality, Oxford: Clarendon Press, 1973, pp. 2-3; ook: Bernard M.S. van Praag, "Ordinal and cardinal utility", Journal of Econometrics 50 (1991), p. 71.

26. Ermest Campbell Mossner, The life of David Hume, Edinburgh [etc.]: Nelson, 1954. p. 477.

27. Moses Mendelssohn, Schreiben an den Herm Diaconus Lavater zu Zürich, JubA, VIL, p. 8.

28. Moses Mendelssohn, Phaedon oder Über die Unsterblichkeit der Seele, Zweytes Gespräch, JubA, III.1, p. 86.

29. Vergelijk: E.M. Barth, "Mannelijk en Vrouwelijk - een verouderde probleemstelling", De Gids 154 (1991), pp. 538-551.

30. Moses Mendelssohn, "Brief aan Hennings", JubA, XIII, p. 65.

31. Moses Mendelssohn, "Was heisst Aufklären?", JubA, VI.1, pp. 113119.

32. Moses Mendelssohn, Morgenstunden oder Vorlesungen über das Dasein Gottes, VII, JubA, III.2, p. 61.

33. Moses Mendelssohn, Jerusalem oder über religiöse Macht und Judenthum, JubA, VIII, p. 156.

34. Geciteerd naar: Alexander Altmann, Die trostvolle Aufkidinung. Studien zur Metaphysik und politischen Theorie Moses Mendelssohns, Stuttgart - Bad Canstatt: Friederich Frommann, 1982 , p. 23. Vergelijk: JubA, I.2, pp. $325-328$.

35. Vergelijk: I.B.H. Abram, Joodse traditie als permanent leren, [Hilversum]: B. Folkertsma Stichting voor Talmudica, [1980]. 
36. In: Condorcet Tableau général de la science qui a pour objet l'application du calcul aux sciences politiques et morales, in: Oeuvres, ed. Arago, 1, pp. 539-573.

37. Wilhelm von Humboldt, "Ober die innere und äussere Organisation der höheren wissenschaftlichen Anstalten in Berlin" in: Werke, IV, Schriften zur Politik und zum Bildungswesen, Stuttgart: J.G. Cotta, 1969 , pp. $255-266$.

38. Wilhelm von Humboldt, "Theorie der Bildung des Menschen", "Uber den Geist der Menschheit", en "Uber die Bedingungen, unter denen Wissenschaft und Kunst in einem Volke gedeihen", in: Werke, I, Schriften zur Antropologie und Geschichte, Stuttgart: J.G. Cotta, 1960 , pp. 234-240, pp. 506-518, en pp. 553-561.

39. Vergelijk: John Stuart Mill, On liberty, Chapter III, in: Collected works, XVIII, p. 261, en John Stuart Mill, Autobiography, in: Collected works, I, pp. 260-261.

40. Vergelijk: John Stuart Mill, On the subjection of women, Chapter I en: Alex Reyer, Auszug aus John Stuart Mill's Unterordnung der Frauen, Graz: Josef Pock, 1869, pp. 57-71; zie ook noot 28.

41. Deze wetenschappelijke wending is al overduidelijk aanwezig in B. Riemann, "Uber die Hypothesen, welche der Geometrie zu Grunde liegen", rede gehouden in 1854 .

42. Alexander von Humboldt, Kosmos, Erster Band, Stuttgart und Augsburg: J.G. Cotta, 1845, p. 37.

43. Hermann Heinrich Gossen, Entwickelung der Gesetze des menschlichen Verkehrs und der daraus fliessenden Regeln für menschliches Handeln, Braunschweig: Friedrich Vieweg und Sohn, 1854, ook herdrukt: Amsterdan: Liberac, 1967, p. 276.

44. W.H. Cliftord, "The ethics of religion", Formightly Review, July 1877, herdrukt in: W.K. Clifford, Lectures and essays, edited by Leslie Stephen and Sir Frederick Pollock, 2 Volumes. London: Macmillan and Co., 1901.

45. W.K. Clifford, "Right and wrong: the scientific ground of their distinction", Forinightly Review, December 1875, reprinted in: Lectures and essays. 
46. W.K. Clifford, "Cosmic emotion", Nineteenth Century, October 1877, reprinted in: Lectures and essays.

47. Archibald Robertson, "Introduction", in: W.K. Clifford, The ethics of belief and other essays, London: Watts \& Co., p. x.

48. Een opwallend voorbeeld is: V.A. Julius, Beschouwingen over de grondslagen der natuurkunde, Breda: Broese \& Co., 1880.

49. Vergelijk: Bertrand Russell, On scientific method in philosophy, Oxford: The Clarendon Press, 1914.

50. Ludwig Wittgenstein," "Logisch-Philosophische Abhandlung", Ammalen der Naturphilosophie 14 (1921), pp. 185-262, 6.4 - 7 .

51. Vergelijk o.a.: Ludwig Wittgenstein, in dagboekaantekeningen van 1937, in: Ludwig Wittgenstein, Vermischte Bemerkungen, herausgegeben won G.H. won Wright, Oxford: Blackwell, p. 29.

52. John Dewey, Reconstruction in philosophy, New York: Henry Holt and Co., 1920, Chapter seven, in: The middle works, 1894-1924, Volume 12 , pp. 172-186.

53. John Dewey, Reconstruction in philosophy, enlarged edition, Boston: The Beacon Press, 1948, "Introduction. Reconstruction as seen twenty-five years later", in: The middle works, 1894-1924, Volume 12, pp. 256-277.

54. Herbert Feigl. "Is science relevant to theology?" Zygon 1 (1966), pp. 191-199; zie ook: "Ethics, religion, and scientific humanism", The Humanist 28 (1968), pp. 21-25. Beide verhandelingen zijn herdrukt in: Herbert Feigl, Inquiries and provocations (zie noot 1).

55. Vergelijk: Bruce Mazlish, "The fourth discontinuity" "Technology and Culture 8 (1967), pp. 1-15, herdrukt in: The computer impact, edited by Irene Taviss, Englewood Cliffs, N.J.: Prentice Hall, 1970, pp. $276-288$.

56. Zie: Margaret A. Bodten, "Human values in a mechanistic universe", in: Human walues, edited by Godfrey Vesey, Sussex: The Harvester Press; New Jersey: Humanities Press, 1978, pp. 135-171, wooral pp. $161-162$. 
57. Margaret A. Boden, "The social implications of intelligent machines", in: The micro-electronics revolution, edited by Tom Forester, Oxford: Basil Blackwell, 1980, pp. 439-451, vooral p. 450; vergelijk: J. Bronowski, Magic, science and civilization, New York: Columbia University Press, 1978, p. 47. Bronowski beroept zich meermalen op Clifford. Overigens is Boden nog wel van mening dat computers en mensen principieel verschillen, doordat computers geen eigen of intrinsieke doeleinden kunnen hebben in dezelfde zin als mensen en dieren die hebben. Zie: Margaret A. Boden, Minds and mechanisms: Philosophical psychology and computational models, Sussex: The Harvester Press, 1981, p. 86.

58. Vergelijk: "Expert systems; how far can they go?", edited by Randall Davis, AI Magazine, (Spring 1989), p. 64; zie voor een uitgebreide standpuntbepaling: Terry Winograd, "Thinking machines: Can there be? Are we?", CSLI Publications 100, Leland Stanford Junior University, 1989; en: Terry Winograd and Fernando Flores, Understanding computers and cognition. A new foundation for design, Norwood, N.J.: Ablex, 1986.

59. A.A.Th.M. van Trier, Wetenschapsbeleid en levensbeschouwing. Een keuze uit zijn geschriften en herinneringen van anderen, Nijmegen: [Stichting Renier Post ], 1987, p. 133. Van Trier wijst op een vroeg voorbeeld van "technology assessment" door Socrates in Plato's Phaedrus: p. 137.

60. Zie: Margaret A. Boden, "Impacts of artificial intelligence", in: Impacts of artificial intelligence, edited by R. Trappl. Amsterdam [etc.]: North-Holland, 1986, pp. 64-77.

61. Vergelijk: René J. Jorna, Knowledge representation and symbols in the mind, Tübingen: Stauffenburg Verlag, 1990. 